\title{
PARTISIPASI MASYARAKAT DALAM PENGELOLAAN OBJEK DAN DAYA TARIK WISATA KORIDOR JALUR LINTAS SELATAN KABUPATEN MALANG
}

\author{
Pramadika Ramanda $^{1}$, Luchman Hakim ${ }^{2}$, Edriana Pangestuti ${ }^{3}$ \\ Fakultas Ilmu Administrasi, Universitas Brawijaya, Malang, Indonesia ${ }^{13}$ \\ Fakultas Matematika Dan Ilmu Pengetahuan Alam, Universitas Brawijaya, Malang, Indonesia ${ }^{2}$ \\ Email :pramadikawork@gmail.com¹, lufehakim@yahoo.com² ${ }^{2}$ edriana_fia@ub.ac.id ${ }^{3}$
}

\begin{abstract}
Local community participation in tourism development has been identified crucial, but it was few discussed in South Malang Regency, East Java. The purpose of this study is to examine the role of the community in the development of natural tourism attraction along Southern corridors on East East Java from Balekambang to Sendang Biru. Field survey and interviews were implemented to generate infromation related to the types of local community participation in tourism along the corridor. This research shows that there are two important bodies in natural resources management that influeces the management of recreation sites mnagament, namely Office of Tourism of Malanag Regency and Perhutani KPH Malang. The form of community participation in the JLS Beach Tourism Corridor in South Malang tends to be dominated by the functional participation model. This participation model forms a community to jointly develop, give advice and plan tourist destinations as a form of appreciation for the existence of local community institutions but the decision makers in planning tourist destinations are dominated by parties outside the community, namely Perhutani.
\end{abstract}

Keywords: local community, resources management

\begin{abstract}
ABSTRAK
Partisipasi masyakat lokal dalam pengembangan pariwisata diketahui sangat penting, tetapi diskusi tentang partisipasi tersebut dalam konteks pesisir Malang Selatan belum banyak dilakukan. Penelitian ini bertujuan untuk mengetahui peran dari komunitas dalam pengembangan wisata alam sepanjang koridor jalur lintas selatan dari Balekambang-Sendang Biru di Kabupaten Malang. Penelitian lapang dilakukan untuk memperoleh informasi terkait bentuk dari partisipasi masyarakat sepanjang koridor JLS Penelitian ini menunjukkan bahwa terdapat dua isntitusi yang terlibat dalam pengelolaan sumbedaya alam atraksi wisata, yaitu pemerintah kabupaten Malang dan Perhutani KPH Malang. Bentuk partisipasi masyarakat di Koridor Wisata Pantai JLS Malang Selatan cenderung didominasi pada model partisipasi fungsional. Model partisipasi ini membentuk masyarakat untuk bersama-sama mengembangkan, memberi saran dan merencanakan destinasi wisata sebagai bentuk apresiasi atas adanya lembaga lokal masyarakat tetapi pengambil keputusan pada perencanaan destinasi wisata didominasi oleh pihak di luar masyarakat, yaitu Perhutani.
\end{abstract}

Keywords: Partisipasi Masyarakat, Manajemen Pengelolaan 


\section{PENDAHULUAN}

Saat ini, pariwisata merupakan salah satu industri yang berkembang pesat di Indonesia. Hampir seluruh daerah berusaha untuk memajukan ekonomi daerahnya melalui pariwisata. Pariwisata merupakan sebuah industri yang sangat penting untuk dikembangkan karena aktifitas yang dilakukan dalam ekosistem tersebut berdampak pada berbagai sektor ekonomi yang ada di masyarakat. Sektor pariwisata dapat dimanfaatkan untuk mendorong perubahan ekonomi dan membuka peluang kerja, meningkatkan pendapatan dan membaiknya kualitas hidup masyarakat lokal

Salah satu model pendekatan yang dapat digunakan dalam pengembangan dan perencanaan dalam studi pariwisata adalah model pendekatan berbasis masyarakat yang biasa disebut pendekatan partisipatif. Pendekatan ini berdasar pada pendekatan pada keberpihakan masyarakat setempat untuk dapat mempertahankan kebudayaan lokalnya dan memberi dampak peningkatan kesejahteraan Ardianto (2012) dan Ernawati et al., (2017). Masyarakat akan ikut terdorong untuk berpartisipasi dalam kegiatan pariwisata bila masyarakat mendapat pengetahuan dan pengertian bahwa mereka mendapat manfaat positif dari adanya pariwisata tersebut. Suwantoro, (1997). Pariwisata berbasis masyarakat saat ini menjadi salah satu tulang punggung dan mempunyai peran penting dalam perkembangan pariwisata di Indonesia. Prinsip utama dari pengembangan pariwisata berbasis masyarakat yaitu bermanfaat bagi masyarakat setempat, memanfaatkan sarana prasarana masyarakat, berskala kecil agar terjalin hubungan timbal balik bagi masyarakat, menerapkan skema produk wisata dan yang utama adalah melibatkan penuh masyarakat. Dalam pendekatan ini, keterlibatan masyarakat mutlak diperlukan karena merupakan perwujudan dari kesadaran, kepedulian dan tanggungjawab masyarakat terhadap pembangunan untuk perbaikan kualitas taraf hidup mereka sendiri. Timothy, D. J. (1999). Goodwin, H. (2002).

Keterlibatan masyarakat ini dimulai pada tahap perencanaan, pengorganisasian dan pengembangan aktifitas program untuk membina kemandiran masyarakat dalam hal ekonomi sosial dan politik. Partisipasi masyarakat sangat dibutuhkan dalam merevitalisasi pembangunan sehingga menghasilkan sebuah arah perubahan yang positif bagi lingkungan sekitarnya. Terdapat beberapa bentuk upaya dalam pengembangan model pemberdayaan berbasis masyarakat, salah satunya adalah peningkatan pemasaran dan aksesibilitas, peningkatan mutu dan pelayanan melalui upgrade sumberdaya manusia. Haywood, K. M. (1988). Timothy, D. J. (1999). Goodwin, H. (2002).

Pariwisata merupakan sebuah industri yang memiliki relasi kuat dengan sumber daya ekonomi, sosial-budaya, dan alam. Para peneliti mengamati bahwa pemanfaat sumberdaya alam-sosial dan budaya rentan terhadap konflik pemanfaatan sumberdaya yang melibatkan masyarakat. Bebagai kajian tentang dapat negatif pariwisata yang harus diterima masyarakat adalah salah satu fakta menarik dalam kajian pariwisata yang menjadi salah satu alasan penting dalam strategi pengembangan wisata berbasis partisipasi masyrakat. Komunitas lokal yang hidup berdampingan dengan sebuah destinasi wisata pada prinsipnya adalah kelompok yang telah menjadi satu bagian yang tidak terpisahkan dalam sistem ekologi pariwisata. Richards, G., \& Hall, D. (Eds.) (2003).

Partisipasi adalah bentuk keterlibatan pikiran dan fisik individu ataupun kelompok dalam sebuah kegiatan untuk mendukung pencapaian tujuan. Terdapat berbagai macam bentuk partisipasi dalam teori partisipasi masyarakat. Berdasarkan bentuknya atau tipenya, menurut Wazir (1999) partisipasi ini dibagi menjadi 7 tipe karakteristik yaitu:

\section{Partisipasi Pasif/ Manipulatif}

Yaitu merupakan tingkat partisipasi paling rendah, dimana hampir tidak ditemui adanya situasi partisipasi yang dilakukan. Dan mempunyai kecenderungan berbentuk indoktrinasi. Dalam tingkatan ini, masyarakat diberi informasi apa yang sedang terjadi dan terjadi pengumuman sepihak oleh pelaksana program tanpa menghiraukan tanggapan dari masyarakat. Selain itu informasi yang disebar hanya sebatas pada kalangan profesional diluar kelompok sasaran (masyarakat). 


\section{Partisipasi Dengan Pemberian Informasi}

Bentuk partisipasi dimana masyarakat ikut serta dalam proses partisipasi melalui pengisian kuisioner dan sejenisnya yang bertujuan untuk menjawab pertanyaan penelitian. Pada model ini tidak ada kesempatan bagi masyarakat untuk terlibat dalam proses partisipasi atau penyelesaian masalah. Hasil dari program juga tidak dibahas bersama masyarakat.

\section{Partisipasi Melalui Konsultasi}

Model partisipasi dimana didalamnya stakeholder mempunyai tempat untuk memberikan suara dan saran dan saran tersebut dilakukan seperti yang mereka harapkan. Bentuk partisipasi dimana masyarakat ikut berkonsultasi, pihak luar akan mendengarkan dan membuat sudut pandangnya sendiri kemudian membantu memberikan definisi permasalahan serta memberi solusi terkait masalah tersebut dengan input dari keluhan masyarakat tersebut. Pada model ini, peluang masyarakat unutk membuat keputusan tidak ada, karena pada model ini para profesional yang dimintai pendapat juga tidak berkewajiban menindaklanjuti pandangan masyarakat.

\section{Partisipasi Intensif Materiil}

Sebuah model partisipasi yang mana masyarakat turur serta berpartisipasi dalam menyumbangkan tenaga kerja atau sumberdaya untuk mendapatkan upah. Dalam model ini masyarakat tidak ikut dalam proses pembelajar serta masyarakat tidak punya andil melanjutkan kegiatan apabila tidak ada upah yang diberikan. Jadi model partisipasi ini sangat bergantung pada faktor upah.

\section{Partisipasi Fungsional}

Sebuah model partisipasi yang didalamnya masyarakat membentuk sebuah kelompok untuk mencapai tujuan yang diinginkan. Pada tahap awal, biasanya kelompok masyarakat tersebut masih bergantung pada pihak dari luar, akan tetapi pada saatnya mereka akan membentuk kelompok mandiri sendiri yang tidak bergantung pada orang asing. Pada tahapan ini keputusan cenderung diambil oleh pihak luar.

\section{Partisipasi Interaktif}

Sebuah model partisipasi masyarakat yang mana didalamnya masyarakt sudah melakukan aktifitas analisa bersama dan menentukan rencana kegiatan dan arah tujuan program.

Model ini cenderung membentuk masyarakat menjadi aktif dalam menyampaikan ide dan pendapat dan masyarakat mempunyai peran untuk mengontrol keputusan mereka sendiri. Sehingga dalam model ini peran partisipasi masyarakat sangat besar.

\section{Self Mobilization}

Sebuah model partisipasi yang merupakan tahapan puncak dari level partisipasi masyarakat.

Pada model ini masyarakat berpartisipasi penuh dalam mengambil keputusan (tanpa ditekan pihak luar). Masyarakat mulai mandiri untuk bekerjasama mencari bantuan dengan pihak luar dan lembaga lain untuk mendapatkan sumberdaya yang dibutuhkan.

Menurut Cohen dan Uphoff dalam Dwiningrum (2009) partisipasi dibedakan menjadi empat jenis, yaitu:

\section{Partisipasi Dalam Pengambilan Keputusan.}

Jenis partisipasi untuk menentukan kesepakatan dari berbagai gagasan dan ide yang ada demi kepentingan bersama. Partisipasi dalam pengambilan keputusan ini menjadi hal yang penting karena masyarakat ikut menentukan arah pembangunan program. Wujud partisipasi dalam pengambilan keputusan ini bermacam-macam, sebagai contoh adalah mengikuti diskusi atau rapat program, sumbangan pemikiran, tanggapan persetujuan atau penolakan terhadap program. Sehingga partisipasi masyarakat dalam tingkatan pengambilan keputusan ini adalah sebuah proses alternatif pemilihan berdasarkan pertimbangan yang menyeluruh dan rasional.

\section{Partisipasi Dalam Pelaksanaan.}

Sebuah tahapan partisipasi dimana tahapan ini didominasi dari dua faktor, yaitu sumberdaya dan dana. Selanjutnya adalah aktifitas yang berkaitan dengan administrasi serta koordinasi dan yang terakhir adalah aktifitas penjabaran program.

Pada tahapan pelaksanaan, sangat dibutuhkan peran dan keterlibatan dari semua stakeholder khususnya pemerintah yang bertugas sebagai sumber utama pembangunan. 


\section{Partisipasi Dalam Pengambilan \\ Kemanfaatan.}

Sebuah tahapan partisipasi dimana aktifitas yang mendominasi dalam tahapan ini berkaitan dengan sejauh mana kualitas dari hasil pelaksanaan program yang telah direncanakan sebelumya, apakah mencapai hasil yang maksimal sehingga memberi manfaat maksimal atau sebaliknya.

\section{Partisipasi Dalam Evaluasi.}

Sebuah tahapan dalam partisipasi yang didalamnya didominasi oleh aktifitas pelaksanaan program. Pada tahapan ini mempunyai tujuan untuk mengetahui bagaimanakah program tersebut berjalan. Keberhasilans ebuah program biasanya ditandai oleh peningkatan output dan seberapa besar prosentase keberhasilan program apakah sesuai target yang dicanangkan atau tidak.

Perkembangan sektor wisata yang cepat di pesisir Malang Selatan adalah salah satu potensi besar dalam meningkatkan kesejahteraan masyarakat sekitar. Sejauh ini, evaluasi tentang keterlibatan masyarakat dalam berbagai aktifitas pariwisata di Malang Selatan belum tersedia sehingga menyulitkan perencanaan pariwisata berkelanjutan berbasis masyarakat. Tujuan dari penelitian ini adalah mendeskripsikan peran masyarakat dan manajemen pengelolaan pada koridor wisata pantai jalur lintas selatan Kabupaten Malang.

\section{METODE PENELITIAN}

\section{Lokasi Penelitian}

Penelitian ini dilakukan sepanjang Jalur Lintas Selatan (JLS) yang terletak di Kabupaten Malang, Jawa Timur. Secara administratif, lokasi koridor malanag selatan terletak pada wilayah administratif Kecamatan Gedangan, kemudian Kecamatan Bantur dan Kecamatan Sumbermanjing Wetan.Secara fisik, kawasan ini dicirikan dengan topografi pesisir, bergelombang dan datar. Kawasan pesisir Malang Selatan ini berbatasan langsung dengan Samudera Indonesia. Kecamatan Bantur memiliki kontur tanah datar. Kecamatan Gedangan memiliki kontur tanah pesisir, sedangkan Kecamatan Sumbermanjing wetan mempunyai kontur tanah bergelombang. Selain itu sebagian topografi dibagian selatan terdiri dari perbukitan kapur.

\section{Pengumpulan Data}

Metode pengumpulan data dalam penelitian koridor wisata ini dilakukan dengan menggunakaneksplorasi dan wawancara terstruktur kepada sejumlah stakeholder yaitu Perhutani dan Dinas Pariwisata Kabupaten Malang dan masyarakat lokal pelaku wisata di sepanjang koridor wisata pantai JLS Malang Selatan. Data lain juga didukung dari dokumen dan literature yang didapat dari Perhutani dan Dinas Pariwisata Kabupaten Malang dan sumber sumber lain yang relevan dengan tujuan penelitian.

Ekplorasi objek dan daya tarik wisata dilakukan dengan pengamatan lapangan secara langsung tentang fasilitas wisata yang ada, kelebihan dan kekurangan pada tiap destinasi wisatadan tipe destinasi wisata berdasarkan keadaan di lapangan. Eksplorasi objek dan daya tarik wisata dilakukan dengan cara berkunjung ke setiap destinasi wisata yang ada di sepanjang koridor kemudian mendeskripsikan objek dan daya tarik tersebut.

Penggalian data terkait bentuk, aspek-aspek terkait tingkatan partisipasi dan sejauh mana partisipasi masyarakat, dan hubunganstakeholder dengan masyarakat diperoleh dengan wawancara. Wawancara dilakukan dengan cara memberi serangkaian pertanyaan yang telah disusun sebelumnya. Dalam melakukan wawancara, peneliti melakukan probing atau penggalian data dan mengeksplore secara terus menerus pada narasumber sampai mendapatkan hasil yang memuaskan. Setelah dilakukan wawancara, hasil data kemudian di transkripsi dan diolah lebih lanjut secara deskriptif, Liamputtong, P., \& Ezzy, D. (2005).

\section{HASIL DAN PEMBAHASAN}

Koridor Wisata Pantai JLS Malang Selatan adalah sebuah jalur yangmerupakan rangkaian jalur lintas selatan di seoanajang Jawa Timur bagian selatan. Jalur ini dibuat dengan maksud mengembangkan wilayah pesisir selatan Kabupaten Malang melalui pembangunan ekonomi dalam upaya meningkatkan produktivitas sumber-sumber alam yang berwawasan lingkungan. Selain itu juga memiliki fungsi lain yaitu untuk memberdayakan dan menngkatkan pendapatan masyarakat melalui kemudahan aksesibilitas. Di Kabupaten Malang, jalur ini telah diselesaian pada ruas pantai Balekambang 
sampaiSendang Biru. Jalur sepanjang Balekambang sampai Sendang Biru mempunyia potensi pesisir yang dapat dioptimalkan dalam kegiatan wisata alam. Penelitian ini mendapatkan 17 pantai yangtelah di gunakan sebagai objek dan daya tarik wisata alam.Titik titik wisata alam tersebut tersebar di tiga kecamatan, yaitu Kecamatan Bantur, Kecamatan Gedangan dan Kecamatan Sumbermanjing Wetan (Gambar 1).

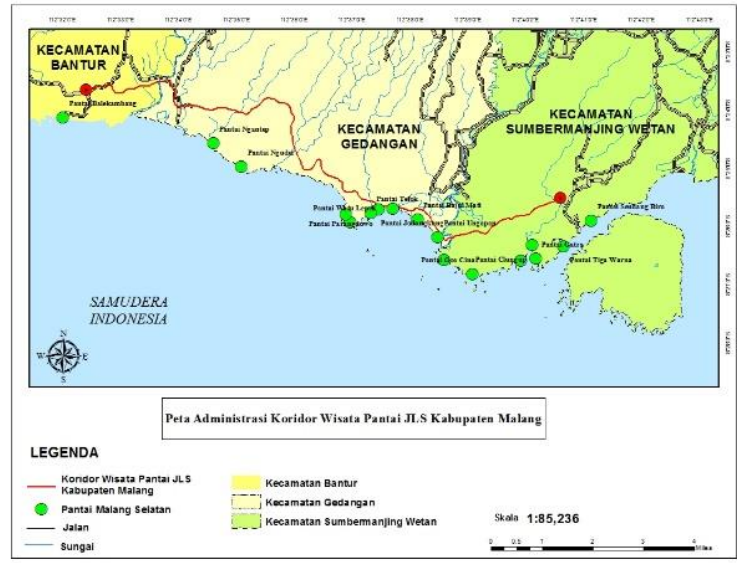

\section{Gambar 1. Distribusi Objek Dan Daya Tarik Wisata Alam Sepanjang Koridor JLS Kabupaten Malang}

\section{Manajemen Pengelolaan}

Manajemen pariwisata dalam sebuah destinasi pariwisata adalah 2 hal yang tidak terpisahkan. Manajemen pariwisata sangat penting sekali keberadaanya karena terkait dengan bagaimana cara pengelolaan sebuah destinasi wisata yang nantinya akan memiliki efek timbal balik terhadap suatu usaha pariwisata yang dilakukan.

Berdasarkan hasil wawancara dapat disimpulkan bahwa secara umum pengelolaan destinasi wisata di pantai terdiri dari Perhutani dan Pemkab Malang dalam hal ini adalah Dinas Pariwisata Kabupaten Malang. Perum Perhutani mengelola 16 destinasi wisata pantai yang berarti sekitar $90 \%$ dari luasan wilayah yang ada di koridor. Sementara Pemkab Malang sebagai induk dari Dinas Pariwisata Kabupaten Malang hanya mengelola 2 destinasi wisata pantai yaitu Pantai Balaikambang dan Pantai Ngliyep. Berdasarkan hasil wawancara kedua dengan PD Jasa Yasa Dinas Pariwisata Kabupaten Malang, terdapat banyak sekali permasalahan pengelolaan pada destinasi wisata pantai yang diakibatkan adanya tumpang tindih pengelolaan dari dua pihak, yaitu Perum Perhutani dan Pemerintah Kabupaten Malang. Hal ini kemudian berdampak pada terbaginya masyarakat ke dalam beberapa kelompok masyarakat yang berbeda. Contohnya adalah terdapat masyarakat yang tergabung di dalam POKDARWIS dibawah binaan Dinas Pariwisata Kabupaten Malang dan kelompok masyarakat yang tergabung dalam LMDH (Lembaga Masyarakat Desa Hutan) dibawah binaan Perhutani KPH Malang.

Dari hasil wawancara yang dilakukan, tumpang tindih kebijakan meliputi antara lain kebijakan pengelolaan destinasi wisata yang berbeda-beda dan tidak satu tujuan. Salah satu contoh masalah yang terjadi adalah pada saat Dinas Pariwisata mempunyai kebijakan ingin mengembangkan sebuah destinasi pantai dan mendatangkan wisatawan, Dinas Pariwisata hanya bisa berpartisipasi dalam menggelar even-even wisata, sedangkan destinasi tersebut dimiliki oleh Perhutani yang biasanya telah mempunyai program sendiri untuk mengembangkan destinasi tersebut. Hal inilah yang menjadi salah satu contoh dampak dari adanya dua pihak yang mengelola destinasi wisata di koridor wisata pantai JLS Malang Selatan. Tidak ada program jangka panjang yang jelas dan terencana untuk mengembangkan destinasi wisata yang ada. Hal ini akan berdampak pada keberlanjutan dan daya sing pariwisata

Peran Dinas Pariwisata sebagai pihak yang seharusnya berwenang dalam pengelolaan pariwisata disepanjang koridor menjadi tidak banyak. Dinas pariwisata lebih banyak bertindak sebagai pembuat aktifitas even wisata dan tidak bertindak sebagai pengelola destinasi wisata. Salah satu contoh permasalahan yang diakibatkan adanya tumpang tindih pengelolaan tersebut, jika terdapat masalah terkait infrastruktur menuju atau dilingkungan sekitar destinasi wisata, Dinas Pariwisata tidak bisa langsung menangani dan memberikan solusi karena wilayah tersebut merupakan lingkup wilayah Perhutani dan diperlukan izin dari Perhutani untuk membangun infrastruktur diwilayah terebut.

Hal ini akan sangat menghambat proses pengembangan destinasi pariwisata. Saat ini, sebagian besar berada dibawah pengelolaan Perhutani KPH Malang yang berada dibawah Kementrian Perhutanan yang memiliki otoritas dan regulasi sendiri. Sulitnya pengembangan dan memajukan sektor pariwisata disebabkan 
belum adanya titik temu yang menguntungkan untuk kedua belah pihak yaitu antara Pemerintah Kabupaten Malang dengan Perhutani KPH Malang.

Berbagai prosedur musyawarah mulai tahap eksekutif, legislatif dan DPRD Jawa Timur dan kementrian Pariwisata belum sampai menghasilkan kesepakatan bersama yang menguntungkan kedua belah pihak.

Menurut wawancara pada Dinas Pariwisata, Pemerintah Kabupaten Malang cenderung mengalami kesulitan untuk memaksimalkan potensi wisata pantai yang ada karena terdapat pengelolaan oleh pihak Perhutani diepanjang koridor tersebut. Hal ini tentu saja berbeda dengan wilayah-wilayah lain yang tidak dikelola oleh perhutani seperti di bali, Lombok, NTB dan NTT sehingga Dinas Pariwisata setempat sangat leluasa untuk mengelola destinasi wisata pantainya.

Menurut salah satu sumber pegawai di Kementrian Pariwisata, bahwa diakui memang Kementrian Pariwisata Pusat sangat sulit untuk masuk kedalam pengelolaan pariwisata area jawa timur karena hamper mayoritas lahan pariwisata dibawah pengelolaan Perhutani dan belum mencapai titik temu kesepakatan pengelolaan.

Dalam permasalahan ini Pemkab Malang juga telah berdiskusi dengan Kementrian Pusat, tetapi kementrian pusat juga tidak bisa berbuat banyak karena lahan pariwisata tersebut dibawah kementrian kehutanan yang menurut mereka akan sangat sulit untuk mendapatkan titik temu terkait pengelolaan tersebut. Pembkab Malang sangat menyetujui adanya Badan Otoritas Pariwisata yang berada dibawah kendali pemerintah pusat untuk pengelolaan pariwisata pesisir Kabupaten Malang. Hal inipun juga disarankan oleh Kementrian Pariwisata Pusat. Lahan pada Koridor Wisata Pantai JLS Malang Selatan dikelola oleh Perhutani KPH Malang, dengan 3 fungsi hutan yaitu $95 \%$ berupa hutan produksi terbatas. Seluas 5\% berupa hutan produksi tetap. (RPJMD Kabupaten Malang 2016-2021)

Dampak dari adanya tumpnag tindih pengelolaan tersebut salah satu diantaranya adalah tidak maksimalnya pendapatan asli daerah (PAD) Kabupaten Malang dari sektor pariwisata. Data dari Dinas Pariwisata dan Kebudayaan (Disparbud) Kabupaten Malang, pada tahun 2016 dengan total jumlah wisatawan mencapai sekitar 5,8 juta, dan sekitar 60 persen masih didominasi kunjungan ke pantai dengan jumlah wisatawan mencapai 3,6 juta wisatawan.

Artinya, daya tarik wisata pantai masih menjadi pilihan utama wisatawan, saat berkunjung ke Kabupaten Malang. Tetapi sayangnya, potensi daya tarik yang tinggi dari wisata kawasan pantai di wilayah Malang Selatan ini belum digarap secara optimal dalam meningkatkan PAD yang kurang berdampak pada peningkatan kesejahteraan masyarakat. Dengan jumlah PAD sektor pariwisata Kabupaten Malang sebesar Rp 1,2 Miliar/tahun pada tahun 2016, dirasakan masih kurang dibandingkan potensi alam yang tinggi. Berdasarkan keterangan dari pihak Dinas Pariwisata Kabupaten Malang, untuk potensi wisata pantai, Pemerintah Kabupaten Malang sudah berupaya penuh utuk mendorong masyarakat desa setempat untuk segera membangun kesepakatan dengan Perhutani. Karena diluar garis batas pantai wilayah tersebut dikelola oleh Perhutani. Sehingga pemerintah Kabupaten Malang tidak dapat ikut mengelola tanpa ada izin dari Perhutani.

Menurut Pemerintah Kabupaten Malang, wisata pantai merupakan andalan karena Kabupaten Malang memiliki potensi wisata pantai cukup banyak. Jika kebijakan MoU antara pemerintah desa dan Perhutani sudah tercipta dengan win-win solution, maka Pemerintah Kabupaten Malang akan dapat mendukung potensi wisata salah satunya dengan kebijakan peningkatan infrastruktur jalan dan fasilitas pendukung lainnya.

Sementara itu di sisi lain pihak pemerintah Kabupaten Malang sebenarnya telah menyambut baik akan hadirnya Badan Otoritas Pengembangan Pariwisata khusus wilayah pantai Malang Selatan, yang merupakan salah satu bentuk rekomendasi dari Kementrian Pariwisata Pusat karena akan memberikan fasilitas dan kewenangan lebih banyak dalam mengembangkan pariwisata lokal. Salah satu bentuk rekomendasi dari Kementrian Pariwisata Pusat adalah pembentukan satuan tugas pariwisata untuk mengoptimalkan pariwisata pantai di Malang Selatan.

Pengelolaan lahan hampir $90 \%$ oleh Perhutani dan pihak Perhutani membayar intensif berupa pajak tiket masuk dari wisatawan yang tiap bulan disetorkan kepada Pemerintah Kabupaten Malang. Salah satu contoh permasalahan lagi adalah jika ingin menggelar sebuah even, pihak Dinas Pariwisata Kabupaten Malang harus membuat izin dulu ke 
Perhutani dan jajaran muspida terkait. Hal ini sangat tidak efektif dalam sebuah sistem pengelolaan destinasi wisata modern. Selama ini yang dilakukan oleh Dinas Pariwisata hanya terpusat pada pihak yang membuat event wisata dan mendorong masyarakat lokal untuk memajukan daerahnya dengan memberi ide atau gagasan di bidang pariwisata. Padahal seharusnya Dinas Pariwisata dapat bertindak dan berfungsi lebih jauh lagi sebagai pengelola destinasi wisata tersebut.

Beberapa permasalahan yang ada di sepanjang koridor wisata pantai JLS Malang Selatan adalah sebagai berikut:

Tabel 1. Permasalahan Koridor Wisata

\begin{tabular}{|c|l|}
\hline No & \multicolumn{1}{|c|}{ Permasalahan } \\
\hline 1 & $\begin{array}{l}\text { Terdapat dua pengelola destinasi wisata ( } \\
\text { Dinas Pariwisata dan Perhutani) yang } \\
\text { berakibat pada kebijakan yang tumpang } \\
\text { tindih dalam membangun kawasan koridor } \\
\text { wisata tersebut }\end{array}$ \\
\hline 2 & $\begin{array}{l}\text { Terdapat 2 pengelolaan pada satu destinasi } \\
\text { wisata }\end{array}$ \\
\hline 3 & Rawan pungutan dan parkir liar \\
\hline 4 & $\begin{array}{l}\text { Terbaginya masyarakat menjadi tiga } \\
\text { kelompok yaitu POKDARWIS, LMDH dan } \\
\text { KTH }\end{array}$ \\
\hline
\end{tabular}

\section{Aktifitas Wisata Koridor}

Aktifitas wisata utama di koridor JLS adalah wisata alam, terutama mengunjungi destinasi wisata pantai. Dibandingkan pada jumlah kunjungan wisatawan tahun 2017, pada kunjungan wisatawan tahun 2018, jumlah wisatawan cenderung menurun pada setiap destinasi wisata pantai. Hal ini disebabkan oleh faktor alam, yakni cuaca buruk sehingga berpotensi menyebabkan banjir rob dan tsunami. Kedua hal inilah yang membuat penurunan drastis jumlah wisatawan di pesisir Kabupaten Malang.

Wisatawan yang berkunjung ke area koridor wisata pantai JLS Malang Selatan sebagian besar didominasi oleh wisatawan domestik. Pada tahun 2017 hampir 7 juta wisatawan berkunjung ke wilayah ini. Biasanya kunjungan wisatawan akan semakin melonjak menjelang akhir tahun.

Kunjungan wisatawan dapat ditingkatkan lagi apabila sudah tersedianya fasilitas yang baik disepanjang destinasi wisata pantai di koridor. Fasilitas adalah sarana prasarana untuk memenuhi kebutuhan wisatawan ketika berwisata, meliputi rumah makan, toilet umum, penginapan, tempat parkir dan lain-lain.

Fasilitas tersebut harus ditingkatkan sesuai dengan standart 4A dalam membangun sebuah destinasi wisata menurut Cooper dalam Sunaryo (2013) yaitu attraction, amenities, aksesibility, dan ancillary service.

\section{Partisipasi Masyarakat}

Partisipasi masyarakat dalam sistem pariwisata yang ada sangat terkait dengan 2 lembaga utama yang mempunyai peran besar di wilayah destinasi wisata malang selatan, yaitu Perhutani KPH Malang dan Dinas Pariwisata Kabupaten Malang. Berdasarkan hasil wawancara dengan Kabag Promosi PD Jasa Yasa diketahui bahwa terdapat kesepakatan pengelolaan dan kemitraan wisata antara masyarakat dengan pihak tersebut. Kemitraan terbagi menjadi 2 , yaitu antara masyarakat yang bekerjasama dengan Pemerintah Kabupaten Malang melalui lembaga POKDARWIS (Kelompok Sadar Wisata) dan masyarakat yang bermitra dengan Perum Perhutani KPH Malang melalui lembaga LMDH (Lembaga Masyarakat Desa Hutan)/ Lembaga Kemitraan DesaPengelola Hutan (LKDPH). Mayoritas pengelolaan destinasi wisata di koridor adalah lembaga LMDH dibawah naungan Perhutani. Sedangkan POKDARWIS berfungsi ketika terdapat event-event yang diadakan oleh Dinas Pariwisata Kabupaten Malang.

Secara umum di sepanjang koridor wisata pantai Malang Selatan terdapat beberapa model partisipasi masyarakat yang diterapkan. Salah satu diantara bentuk partisipasi masyarakat adalah pembentukan POKDARWIS dan LMDH dan beberapa kelompok masyarakat lainnya. Beberapa diantaranya adalah kelompok Clungup Mangroove Conservation (CMC) yang membawahi destinasi pantai Pantai Clungup, Pantai Tiga Warna dan Pantai Gatra dan Yayasan Bhakti Alam Sendang Biru. Selain itu terdapat LMDH Tani Maju yang membawahi Pantai Ungapan, Pantai Batu Bengkung dan Pantai Bajul Mati. Kemudian terdapat LMDH Wonoharjo yang membawahi Pantai Goa Cina. Selanjutnya LMDH Wonodadi yang berada di pantai Balekambang. 
Secara umum bentuk partisipasi masyarakat dibagi menjadi 2. Yaitu partisipasi masyarakat yang tergabung didalam POKDARWIS dibawah binaan lembaga pemerintah yaitu Dinas Pariwisata Kabupaten Malang dan selain itu juga terdapat masyarakat yang tergabung dalam LMDH dibawah binaan lembaga Perhutani KPH Malang.

Salah satu bentuk partisipasi yang dilakukan oleh masyarakat yang tergabung dalam POKDARWIS adalah ikut berpartisipasi dalam even-even pariwisata yang digelar oleh Dinas Pariwisata Kabupaten Malang. Hal ini dikarenakan sebagian besar lahan pariwisata di pesisir Malang Selatan dimiliki oleh Perhutani KPH Malang. Sedangkan untuk masyarakat yang bergabung dalam LMDH dibawah naungan Perhutani KPH Malang berpartisipasi dalam pengelolaan teknis beberapa destinasi wisata pantai di sepanjang koridor wisata. Selain itu masyarakat juga berpartisipasi dalam bentuk pikiran, masyarakat ikut serta mengikuti forum-forum pengembangan pariwisata, tetapi masyarakat berperan tidak aktif dalam mengambil keputusan didalam forum, sehingga masyarakat hanya berperan aktif dalam memberikan saran dan pendapat saja. Masyarakat juga turut berpartisipasi dalam mengelola pariwisata yang meliputi tenaga pemungut retribusi, juru parkir, juru keamanan, dan juga guide untuk wisatawan.

Berikut ini merupakan tabel pengelolaan dan pemilik lahan pada destinasi wisata pantai yang ada di sepanjang koridor wisata. (Tabel 1)

Tabel 2. Pengelola \& Insitusi Penanggung Jawab Kawasan Wisata Di JLS Malang Selatan

\begin{tabular}{|c|l|l|l|}
\hline No & $\begin{array}{l}\text { Nama } \\
\text { Destinasi } \\
\text { Wisata }\end{array}$ & Pengelola & Pemilik \\
\hline 1 & $\begin{array}{l}\text { Pantai } \\
\text { Sendang Biru }\end{array}$ & $\begin{array}{l}\text { Yayasan Bhakti } \\
\text { Alam }\end{array}$ & $\begin{array}{l}\text { Perhutani } \\
\text { KPH } \\
\text { Malang }\end{array}$ \\
\hline 2 & $\begin{array}{l}\text { Pantai } \\
\text { Clungup }\end{array}$ & $\begin{array}{l}\text { CMC } \\
\text { (Clungup } \\
\text { Mangroove } \\
\text { Conservation) }\end{array}$ & $\begin{array}{l}\text { Perhutani } \\
\text { KPH } \\
\text { Malang }\end{array}$ \\
\hline 3 & Pantai Gatra & $\begin{array}{l}\text { CMC } \\
\text { (Clungup } \\
\text { Mangroove } \\
\text { Conservation) }\end{array}$ & $\begin{array}{l}\text { Perhutani } \\
\text { KPH } \\
\text { Malang }\end{array}$ \\
\hline
\end{tabular}

\begin{tabular}{|c|c|c|c|}
\hline No & $\begin{array}{l}\text { Nama } \\
\text { Destinasi } \\
\text { Wisata }\end{array}$ & Pengelola & Pemilik \\
\hline 4 & $\begin{array}{l}\text { Pantai Tiga } \\
\text { Warna }\end{array}$ & $\begin{array}{l}\text { CMC } \\
\text { (Clungup } \\
\text { Mangroove } \\
\text { Conservation) }\end{array}$ & $\begin{array}{l}\text { Perhutani } \\
\mathrm{KPH} \\
\text { Malang }\end{array}$ \\
\hline 5 & $\begin{array}{l}\text { Pantai Teluk } \\
\text { Asmoro }\end{array}$ & $\begin{array}{ll}\text { LMDH } & \text { Desa } \\
\text { Sitiharjo } & \end{array}$ & $\begin{array}{l}\text { Perhutani } \\
\mathrm{KPH} \\
\text { Malang }\end{array}$ \\
\hline 6 & $\begin{array}{l}\text { Pantai Goa } \\
\text { Cina }\end{array}$ & $\begin{array}{l}\text { LMDH } \\
\text { Wonoharjo } \\
\text { Abadi }\end{array}$ & $\begin{array}{l}\text { Perhutani } \\
\text { KPH } \\
\text { Malang }\end{array}$ \\
\hline 7 & $\begin{array}{l}\text { Pantai Watu } \\
\text { Leter }\end{array}$ & $\begin{array}{l}\text { LMDH } \\
\text { Wonoharjo } \\
\text { Abadi }\end{array}$ & $\begin{array}{l}\text { Perhutani } \\
\text { KPH } \\
\text { Malang }\end{array}$ \\
\hline 8 & $\begin{array}{l}\text { Pantai } \\
\text { Ungapan }\end{array}$ & $\begin{array}{ll}\text { LMDH } & \text { Tani } \\
\text { Maju } & \end{array}$ & $\begin{array}{l}\text { Perhutani } \\
\text { KPH } \\
\text { Malang }\end{array}$ \\
\hline 9 & $\begin{array}{l}\text { Pantai } \\
\text { Bajulmati }\end{array}$ & $\begin{array}{ll}\text { LMDH } & \text { Tani } \\
\text { Maju } & \end{array}$ & $\begin{array}{l}\text { Perhutani } \\
\text { KPH } \\
\text { Malang }\end{array}$ \\
\hline 10 & $\begin{array}{l}\text { Pantai Batu } \\
\text { Bengkung }\end{array}$ & $\begin{array}{l}\text { LMDH Tani } \\
\text { Maju }\end{array}$ & $\begin{array}{l}\text { Perhutani } \\
\mathrm{KPH} \\
\text { Malang }\end{array}$ \\
\hline 11 & $\begin{array}{l}\text { Pantai Watu } \\
\text { Lepek }\end{array}$ & $\begin{array}{ll}\text { LMDH } & \text { Tani } \\
\text { Maju } & \end{array}$ & $\begin{array}{l}\text { Perhutani } \\
\mathrm{KPH} \\
\text { Malang }\end{array}$ \\
\hline 12 & $\begin{array}{l}\text { Pantai } \\
\text { Jolangkung }\end{array}$ & $\begin{array}{ll}\text { LMDH Desa } \\
\text { Gajahrejo }\end{array}$ & $\begin{array}{l}\text { Perhutani } \\
\text { KPH } \\
\text { Malang }\end{array}$ \\
\hline 13 & $\begin{array}{l}\text { Pantai } \\
\text { Parangdowo }\end{array}$ & $\begin{array}{ll}\text { LMDH Desa } \\
\text { Gajahrejo }\end{array}$ & $\begin{array}{l}\text { Perhutani } \\
\text { KPH } \\
\text { Malang }\end{array}$ \\
\hline 14 & Pantai Telok & $\begin{array}{l}\text { LMDH Desa } \\
\text { Gajahrejo }\end{array}$ & $\begin{array}{l}\text { Perhutani } \\
\text { KPH } \\
\text { Malang }\end{array}$ \\
\hline 15 & $\begin{array}{l}\text { Pantai } \\
\text { Ngudel }\end{array}$ & $\begin{array}{ll}\text { LMDH } & \text { Desa } \\
\text { Sindurejo } & \end{array}$ & $\begin{array}{l}\text { Perhutani } \\
\mathrm{KPH} \\
\text { Malang }\end{array}$ \\
\hline 16 & $\begin{array}{l}\text { Pantai } \\
\text { Nganteb }\end{array}$ & $\begin{array}{l}\text { LMDH } \\
\text { Wanakarya }\end{array}$ & $\begin{array}{l}\text { Perhutani } \\
\text { KPH } \\
\text { Malang }\end{array}$ \\
\hline 17 & $\begin{array}{l}\text { Pantai } \\
\text { Balekambang }\end{array}$ & PD Jasa Yasa & $\begin{array}{l}\text { Perhutani } \\
\text { KPH } \\
\text { Malang }\end{array}$ \\
\hline
\end{tabular}

Sumber: Hasil Penelitian 2019

Sebagian besar mitra kerja kelompok masyarakat pada destinasi wisata dikawasan koridor wisata pantai malang selatan adalah Perhutani KPH Malang dengan perjanjian kerjasama tentang pendapatan tiket dan berbagai hal lainnya. Berdasarkan data wawancara, diketahui bahwa $20 \%$ hasil pendapatan Perhutani diserahkan kepada Pemkab Malang sebagai hasil setoran pajak. Sedangkan untuk Perhutani $35 \%, \mathrm{LMDH}$ 
sekitar 28-30\%. Sisanya untuk mitra kelola seperti desa, muspika, masing-masing mendapatkan $2-5 \%$.

Dari hasil analisi yang telah diakukan, terlihat bahwa bentuk partisipasi masyarakat adalah Partisipasi Fungsional (Functional Participation). Dalam bentuk ini, pengambilan keputusan perencanaan cenderung pada model partisipasi fungsional dimana Perhutani bertindak sebagai pengambil keputusan perencanaan destinasi wisata. Menurut para peneliti, hal itu antara lain disebabkan oleh faktor kualitas sumberdaya manusia yang masih terlampau rendah sehingga tidak mempunyai daya tawar dalam pengembangan negosiasinegosiasi dalam pemanfaatana sumberdaya lama. Menurut Baum, T. (2007), sektor pariwisata, terutama pada negara berkembang masih menyisakan permasalahan sumberdaya manusia, dimana peningkatan kapasitas sumberdaya manusia sangat dibutuhkan dalam industri wisata. Hal ini terutama relevan dengan fakta bahwa industri pariwisata adalah industri yang terkait dengan pemanfaatan berbagai sumberdaya alam dalam kewenangan insitusi dan kepemikian yang berbeda. Sebagai industri berbasis jasa, layanan prima adalah bagian penting yang sangat terkait dengan sumberdaya manusia.

\section{KESIMPULAN DAN SARAN}

Berdasarkan hasil analisis dan pembahasan, dapat disimpulkan sebagai berikut:

1. Terdapat 2 manajemen pengelolaan di sepanjang koridor wisata pantai JLS Malang Selatan. Sebanyak 16 pantai dikelola oleh Perhutani KPH Malang dan satu pantai yaitu pantai Balekambang dikelola oleh Dinas Pariwisata Kabupaten Malang.

2. Pada pengelolaan koridor wisata pantai JLS Malang Selatan bentuk partisipasi masyarakat adalah Partisipasi Fungsional (Functional Participation) dimana pengambilan keputusan perencanaan cenderung pada model partisipasi fungsional dimana Perhutani bertindak sebagai pengambil keputusan perencanaan destinasi wisata. Masyarakat akan ikut berpartisipasi melalui cara pemberian ide pembuatan kelompok yang nantinya akan berkonsentrasi dalam pengembangan pariwisata. Selain itu dalam penentuan tujuan rencana pembangunan destinasi wisata masyarakat juga turut dilibatkan tetapi keputusan tersebut diambil oleh pihak dari luar masyarakat desa, dalam hal ini adalah pihak Perhutani KPH Malang.

\section{DAFTAR PUSTAKA}

Alfitri. 2011. Community Development: Teori dan Aplikasi. Yogyakarta: Pustaka Pelajar.

Adisasmita, Raharjo. 2006. Membangun Desa Partisipatif. Yogyakarta: Graha Ilmu.

Ardianto, E. 2012. Dimensions of CommunityBased Tourism: A case of surf community in Bali, Indonesia. Journal of Tourism Research, 38.

Baiquni, M. 2010. Pariwisata Berkelanjutan dalam Pusaran Krisis Global, Pariwisata dan Krisis Lingkungan Global. Udayana University Press.Denpasar, Bali.

Baum, T. 2007. Human Resources In Tourism: Still Waiting For Change. Tourism Management, 28(6), 1383-1399.

Cohen and Uphoff. 1977. Rural Development Participation. Cornel University. New York.

Demartoto, Argyo. 2009. Pembangunan Pariwisata Berbasis Masyarakat Surakarta: Sebelas Maret University Press.

Dwiningrum, Siti Irene Astuti. 2011. Desentralisasi dan Partisipasi Masyarakat dalam Pendidikan. Yogyakarta: Pustaka Pelajar

Ernawati, N. M., Sanders, D., \& Dowling, R. 2017. Host-Guest Orientations Of Community-Based Tourism Products: A Case Study In Bali Indonesia. International Journal of Tourism Research, 19(3), 367-382. 
Fandeli. Chafid. 2000. Pengusaha Ekowisata. Fakultas Kehutanan Universitas Gadjah Mada. Yogyakarta.

Goodwin, H. 2002. Local Community Involvement In Tourism Around National Parks: Opportunities And Constraints. Current Issues in tourism, 5(3-4), 338-360.

Hakim, L., Soemarno, M., \& Hong, S. K. 2012. Challenges For Conserving Biodiversity And Developing Sustainable Island Tourism In North Sulawesi Province, Indonesia. Journal of Ecology and Environment, 35(2), 61-71.

Haywood, K. M. 1988. Responsible And Responsive Tourism Planning In The Community. Tourism management, 9(2), 105-118.

Hermantoro, Hengky, 2011. Creative Based Tourism: Dari Wisata Rekreatif Menuju Wisata Kreatif. Aditri.

Hobley, M. 1996. In Rural Development Forestry Study Guide 3.London: Rural Development Forestry Network.

Huraerah, Abu. 2011. Pengorganisasian \& Pengembangan Masyarakat. Bandung: Humaniora.

Liamputtong, P., \& Ezzy, D. 2005. Qualitative research methods (Vol. 2). Melbourne: Oxford university press.

Mulyadin. 2001. Pembangunan Desa Wisata L Pelaksanaan Undang-Undang Otonomi Daerah. Info Sosial Ekonomi Vol 2. No 1

Priaksukmana, Soetarso \& R. Mohammad

Richards, G., \& Hall, D. (Eds.). 2003. Tourism And Sustainable Community Development (Vol. 7). Psychology Press.

RPJMD Kabupaten Malang 2016-2021.

Sugiyarto, G., Blake, A., \& Sinclair, M. T. 2003. Tourism and globalization:
Economic impact in Indonesia. Annals of Tourism Research, 30(3), 683-701.

Sunaryo, Bambang, 2013, Kebijakan Pembangunan Destinasi Pariwisata Konsep dan Aplikasinya Indonesia, Yogyakarta, Gava Media.

Soemarwoto. 1997. Ekologi. Lingkungan Hidup dan Pembangunan. Penerbit: Djambatan. Jakarta.

Timothy, D. J. 1999. Participatory Planning a View of Tourism In Indonesia. Annals of Tourism Research, 26(2), 371-391.

Wahab, Salah. 1975. Tourism Management. London: Tourism International Press.

Wazir Ws, 1999. Panduan Penguatan Manejemen Lembaga Swadaya Masyarakat. Jakarta: Sekretariat Bina Desa.

Windiyarti,Dara. $1994 . \quad$ Dampak Pengembangan Pariwisata Terhadap Kehidupan Sosial Di Daerah Timor Timur. Departemen Pendidikan Dan Kebudayaan Timor Timur.

Wicaksono, Hanif Wahyu. 2011. Partisipasi Masyarakat Dalam Tahap Perencanaan, Pelaksanaan dan Pemanfaatan Pengembangan Obyek Wisata Museum Gunung Merapi Di Dusun banteng, Kelurahan Hargobinangun, Kabupaten Sleman, Daerah Istimewa Yogyakarta. Skripsi. Surakarta: Fakultas Ilmu Sosial dan Ilmu Politik. Universitas Sebelas Maret Surakarta.

Woodside, A, et al. 2008. Travel Story Telling Theory And Practice. Boston College; University of Hawaii.

Yoeti, Oka. 2016. Perencanaan dan Pengembangan Pariwisata.Balai Pustaka.

UU 10 tahun 2009. 